\title{
大学教授職研究は何をなしうるか : 成果と展望
}

\author{
湯川やよい* 坂無 淳** 村澤 昌崇***
}

\section{【要旨】}

大学教授職研究は, タブ一視されがちな大学教員世界に切り込む挑戦的領域で あり, 既存研究の貢献は大きい。しかしその成熟ゆえに, 近年の大学内外の変化 を踏まえた「専門職の社会学」研究としての意義づけの再確認と, 方法論的展開 の促進が不可欠である。

この問題意識のもと, 本稿では, (1)ミクロレベルでの相互作用の研究，(2)男女 共同参画をめぐる政策研究，の二つのレビューを行った。その結果，(1)について は, 大学教授職研究での相互作用研究における「批判的な社会学」の視点亡質的 アプローチの不足を指摘しつつ, 大学教員を複数の社会学的变数から成る多様性 ある集団として捉えなおすことを提案した。(2)のマクロレベルについては，男女 共同参画に関する大学教授職研究からの批判的検討と知見の提供の不足を指摘し, それを乗り越える分析の可能性を論じた。

最後に, こうした専門研究コミュニティ外部の問題意識との接続を通じ, 建設 的批判や対話を積み重ねることで，大学教授職研究の裙野を広げることの必要性 を提言した。

キーワード : 大学教授職, ジェンダー, 専門職の社会学

\footnotetext{
*愛知大学 $* *$ 福岡県立大学 $* * *$ 広島大学
} 


\section{1. はじめに}

大学教員は, 知識の発見・統合・応用・教育 (Boyer, 訳書, 1996) をミッショ ンとする “専門職” であり, 学生, 職員と並び, 高等教育の主たるアクターとして 重要な研究対象である。そのような大学教員も, かつては, 筒井康隆の『文学部唯 野教授』（1987）や，㮣田（1991），川成（1995）らにより，毒気たっぷりに，そし て痛烈にその内幕を暴露されたものだった。これらの出版は当時大きな話題となっ たが，㧍そらく，一般には知られることも希な大学の中における地位や権力を巡る 人間模様が，衆目の関心をひいたのだうう。

しかし，周知の通り，大学教員を取り巻く現況は厳しく，分野によっては存続の 危機にさえ立たされている。こうした状況に対し，これまでの大学教授職研究は， 大学教員をサポートできるような, そして同時に大学教員以外の人々の疑問や関心 に正面から応えうるような，理論・実証双方における有益な知見を導けてきたのか。 この問いこそが, 本稿執筆のきっかけである。そこで本稿では, これまで議論され てきた大学教授職研究を振り返り, その功績を整理するとともに, 論じられてこな かった諸課題に光を当て，その中で近年高等教育研究の外側で取り組まれつつある いくつかの論点の重要性を提起しつつ, これからあるべき大学教授職研究の「社会 学」を展望したい。具体的には, 質的方法の重要性, ジェンダー論や男女共同参画 社会論そして多様性などの観点からの問題提起を試みる。

そもそも社会学とは社会の内側にいる私たちが，自己省察的に社会を捉え直す視 点を持つ学問である。著名な例をあげるだけでも, Merton（訳書, 1961）の学問 的出発点は科学社会学であったし, Weber（訳書, 1980), Mills（訳書, 1984）, Bourdieu et Passeron（訳書, 1991）らは, 大学や知識人, そして大学教授職にか んする自己省察から社会学的に重要な知見を生み出した。そうした意味において， 大学教授職研究は社会学の典型だとさえいえる。だとすれば, 例えば大学教授職に かんする社会学的に堅実な経験的調査から大学教授職にかんする中範囲の理論を構 築すること，さらにはそこから専門職論一般の理論化を行うことができないだろう か。大学教授職研究の知見をもっと社会学に還元すること, 社会学の知見を大学教 授職が現在抱えている諸問題の解明と解決に活用すること,このふたつを行うこと がまさに我々社会学者の仕事ではないだろうか。 


\section{2. 大学教授職研究の特色と課題}

\section{1. 手がけてきた成果}

では，大学教員にかんする研究は，何を手がけてきたのか。阿曾沼（2010）のレ ビューによれば, 専門職論, 学閥, 移動, キャリア, 学問生産性と (研究) 評価, 労働環境, 報償体系, 科学のライフサイクル, 科学者集団の開放化・多様化など多 岐にわたる。

この研究領域の一翼を担ったのは，新堀通也とその後継者による研究者集団であ り，日本の大学教授職研究は彼らが毫引したとも言える。研究全体の俯瞰は阿曾沼 （2010）に譲るが, 教育社会学を舞台とした研究としては, 主として専門職論, 学 閥，移動・キャリア，そして大学教授職にかんする国際比較研究がある。まず専門 職論は, 大学教授職の特徴として「専門職を生み出す専門職」「科学的知識生産」 「資格と養成システムの不在」「顧客の不在」「研究・教育・社会貢献」の 5 つを指 摘した（新堀 1984）。学閥研究は, 東大等旧帝国大学を筆頭とした国立大学によ る研究者市場の寡占と閉塞状況を問題化した（新堀 1969）。後続の研究は, 教員 の移動・キャリア・人事（公募制・任期制など）にかんする研究が山野井 (1990), 山野井編（2007）により牽引され, 移動の多様性の類型化や, 流動性の多寡・人事 の変容がもたらす教員の行動変容が言及された。そして有本・江原ら（1996）の研 究は, 世界初とも言える大学教員の全方位的国際調査を展開し, 後に続く「広島大 学型」とも言える大学教授職研究（有本 2005b 有本編 2008, 2011）の雛形を 作った ${ }^{(2)}$ 。

\section{2. 課題}

ただし, 大学を取り巻く環境の変容や学術的な観点から, 大学教授職研究には, これまで以上に着手すべき課題が山積している。以下，内省的に諸課題を指摘して みよう。

\subsection{1. 研究的関心と実務的・現代的課題への関心のズレ}

一つは，一部次節で詳細に取り上げるが，現代的・実務的課題への対応である。 近年では, 外国人・民間等非伝統的キャリアからの参入 ${ }^{(3)}$, 非常勤講師・任期付き 教員 ${ }^{(4)}$ ・ ポスドク等不安定な身分の教員・研究者の増加, 卓越大学院・指定国立大 学などの「選択と集中」政策の展開等の環境変化が激しい。これらが及ぼす, キャ リアやワークライフバランスの不安定化, 教員供給の寡占化への懸念, 研究活動や 
教育・学生に及ぼす影響 ${ }^{(5)}$ など, 課題は多い。さらに諸々の新しい教育実践の無批 判な導入,「大学ランキング」の浸透がもたらす数量的業績評価の問題, 多発する 研究不正，人口減少期における大学経営問題など，実践的課題も多い。しかし，こ うした問題は「高学歴ワーキングプア」（水月２007）等の読み物を通じての問題 化に留まるか, 一部（有本 2016）を除き未対応である ${ }^{(6)}$ 。

\subsection{2. 問題設定と研究枠組みの適切性・方法論的脆弱性}

研究デザインについてはどうか。この点については, 研究枠組みの慣習化 (Rhoardes 訳書，2015，p.178），国際比較に対する「より繊細で深遠な違いをきち んと調査し始めてもいない」（Rhoardes 訳書, 2015, p.183）等の指摘がある。定 点観測は重要だが，調査の継続自体の目的化が懸念される。また，再考を要する仮 説 ${ }^{(7)}$ も見受けられる。

分析方法については，たとえば，データの代表性にかんする検証不足や，手法の 高度化に課題を残し ${ }^{(8)}$ ，パネルデータの取得や，3節でも詳述するように，フィー ルドワークなどの手法も取り入れた質・量両面からの探索が求められるが, 現状で はほとんどみられない ${ }^{(9)}$ 。

\subsection{3. 社会学的な意義の再考}

しかし，本質的課題は，「研究課題が社会学のディシプリンの考え方によって導 かれる」側面（Gumport 訳書，2015，p.429）の弱体化ではないか。たとえば，近 現代社会形成における科学者の役割, 科学者の規範（Merton 1979）や業績主義 · メリトクラシー原理の大学教員への浸透状況, 研究者集団におけるマタイ効果の存 在等, 問うべき社会学固有の命題は多い。特に専門職研究の視点が現況ではそしく, そして 3 節にて触れるように, 支援系職員等の新しい研究対象やこれらと関連する マイノリティ・女性にかんする視点も弱い。その結果, 諸差別にかんする研究や フェミニズムの視点での議論も少ない。また, 労働組合を典型とする自治や学問の 自由を保護するための集団的権力行使・行動や，世界的には関心の高い年金等（神 代 2016, 渡邊 2014）も問題化されていない。

\section{3. 何が問題なのかー小括}

このように，大学教授職研究はその萌芽期には基礎的な情報を提供する役割を担 いつつ, 近年では従来の研究範囲を超えた課題の山積に対する知見の提供不足や, 学術的意義の再考という課題がある。これらの問題は, 大学教授職の研究者に内在 的な問題である以上に, 大学教授職研究の成果を直視せず, 自らの問題として内面 
化しなかった社会学者 ${ }^{(10)}$ や他専門分野の大学人の問題でもある。ただし, 社会学の 枠の中で, 大学教授職研究を理論・方法の面で推進する研究が無かったわけではな い。全ての研究を網羅はできないが， 3 節では，特に既存研究で相対的に手薄と思 われるテーマ領域の一部に焦点をあて, 今後研究の発展可能性があると思われる論 点を整理・紹介していきたい。

たとえばGardner and Mendoza（2010, pp. 5-6）は, 英語圈での研究者養成研 究の動向レビューに扔いて, その社会化過程を批判的に論じる諸研究が共有する主 たる問題意識・分析視点を, 主に人種化・ジェンダー化された経験に注目するもの, 特定の専門領域を通じた社会化や特定の専門職（大学教授職以外も含む）への社会 化に注目したもの，抒よび市場化の影響に注目したものに大別し，整理している ${ }^{(11)}$ 本稿でこれらのポイントを全面的に検討することは到底できないが，ここでは第一 歩として, 日本国内において社会的関心は寄せられているもののそれに比して蓄積 の薄い「ジェンダー」に注目した論点整理を行いたい。具体的には，1）ミクロレ

ベル：相互作用研究，2）、クロレベル：男女共同参画政策と大学教授職のそれぞ れの領域に大別し，いかなる課題が残されており，今後どのような社会学的探究が 望まれるのか, 検討する。

\section{3. 大学教授職研究の新たな展開可能性 : ジェンダーの視点を手がかり にして}

\section{1. ミクロレベル：相互作用研究}

2 節で概観したと㧍り，国内の大学教授職研究は，マクロデー夕を用いた大学 教員市場の研究や国際比較研究に集中してきた。一方, 教員間の日常的なかかわり や教員一学生間の関係性（ミクロレベルでの相互作用），およびその背景にある組

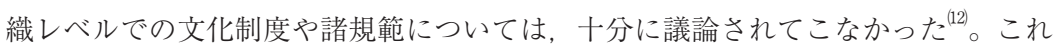
は必ずしも国内研究に限った傾向ではなく, 教員一学生間や教員同士の社会的関係 にかんする研究の質的広がりが薄いことは, 海外研究でも指摘されている (Rhoardes 訳書, 2015, pp.168-169)。だが, 初等・中等教育の社会学研究がマク ロからミクロまで多角的検討を行ってきた状況に照らせば, 大学教授職研究におい ても，今後，ミクロレベルにかんして先行する理論を踏まえた実証研究の充実が期 待される。

そのための糸口として, ここでは特に，(1)「批判的な社会学」の視点（Bura-

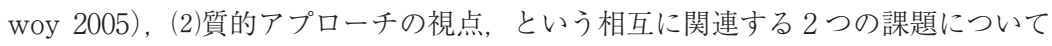


検討したい。なぜなら, 既存研究に抢けるこの 2 つの視点の不足が, ミクロレベル 研究の蓄積の薄さの一因であると思われるからだ。もちろん, 研究対象の範囲, 調 查技法, 調査者の世界観はそれぞれ相対的に独立した観点であり，「批判的な社会 学」の立場に立つことや質的アプローチをとることが，ミクロレベルの観察と必然 的に重なりあうわけではない。ただ，それにもかかわらず，これらが総じて既存の 大学教授職研究の中で相対的に欠けているのだとすれば, その偶発的な「欠如の重 なり」に注目することは, 単なる「批判のための批判」ではなく, 大学教員研究の さらなる発展を展望する上での建設的な手がかりとなるはずだ。

まず，第1の課題である「批判的な社会学 (critical sociology)」であるが，ここ では M. Burawoy が分類した米国社会学のパラダイムのひとつとしてこの言葉を 用いている。具体的には, フェミニズム, 批判的人種理論, クィア理論など, 特に 「大きな物語」が否定された 20 世紀末英語圈を舞台に台頭したさまざまなマイノリ ティ研究による社会学を指す（Burawoy 2005, p.10)。その特徵は, 単に女性やマ イノリティを研究対象とするのではなく, 既存研究 (「専門的な社会学」) がマジョ リテイ側の常識から当該社会を観察してきたことの限界を指摘し，それを乗り越え るため社会的に周辺化された立ち位置から既存研究の問いの枠組みそのものを設定 しなおし，社会変革の方向性を示そうとする点にある。

では，なぜ，「批判的な社会学」の視点が大学教員の相互作用を論じる上で必要 なのだろうか。その答えのひとつを, 学生の多様化と大学教員の多様化という変化 の中に見出すことができる。

日本国内に扮いて, 大学内部での人々の多様化は，11大学知・大学教育の大衆化 (竹内 2001等), (2)非伝統的セクター (女性学生, 留学生, 社会人学生) の増加 （近田 2008, 米澤 2010等) に加え, さまざまな障害やマイノリテイ性をもつ学 生層の可視化 (日本障害者高等教育支援センター問題研究会 2001等), (3)非常勤 講師やポストドクターの雇用・生活問題（大学非常勤講師問題会議 2000等)，(4) 女性研究者支援 ${ }^{(3)}$ など,「大学の変化」をめぐる諸問題として論じられる傾向にあ る。まず，(1)，(2)はいずれも，エリート段階からマス，ユニバーサル段階へと変化 した大学における構成員の多様化を端的に映し出す問題として高等教育研究者の関 心も集めてきたが，そこでの観察対象は，多くの場合学生集団に限定されている。 しかし, 大学構成員の多様化を「学生の問題」に限定する傾向は, 教員集団があた かも伝統的集団として不変的な規範・慣習を共有しているかのような固定的思考を 導く危険性がある。なお, ここでいう「伝統的」集団とは, 主に異性愛・シスジェ 
ンダー ${ }^{(14)}$ の健常者男性で外国にルーツをもたず常勤職に就く教員集団を想定してい る。だが，今日的な「デモバーシティ」（Kernan eds. 訳書 2001）を読み解くた めには，学生集団だけでなく教員集団もまた単一ではないとの視点を取り入れるこ とが, 不可欠である。

これに対して, (3)や(4)は, 教員集団内部の多様性に焦点を当てたものではあるが, (3)の非常勤講師等についてはそれ自体研究の蓄積が少ないことに加え（喜多村 1996)，第 1 節でも言及したとおり, ジャーナリスティックな読み物, 問題提起型 の出版物が先行する形で議論されており, その社会学的な研究は決して多くない (例外として北野 2015など)。

(4)の女性研究者支援については，3.2で後述するとおり，政策的関心にも後押し され活発な議論がなされる領域である。だが, 主要な高等教育研究ジャーナル論文 の多くは性別変数としてのみジェンダーを扱うに留まっておりそこにフェミニズム の視点を明確に取り入れた分析は決して多くないという Hart（2006）の指摘は, 日本国内の研究動向においても当てはまる（なお， 3.2.で後述の通り加野 1988 な ど先駆的研究も存在するが, これを近年の社会的・経済的変化を踏まえて発展的に 継承する研究は多くない)。

こうした状況の中, 上揭 Hart（2006）の研究などを肯定的に取り上げる Rhoardes (2015, 訳書) は, 批判的なジェンダー視点での分析を取り入れること で，米国の大学教授職研究において次のような新たな問いが浮かび上がることを例 示している——とえば, 社会的に周辺化されたマイノリティ学生をめぐる諸課題 にかんしてどのような教員がどのようにコミットしているのか（Rhoardes 訳書, 2015, p.168), 特定の教育, サービス活動について女性教員やマイノリティ教員が 過剰に負担を割り当てられる現状があるのではないか（同上書, p.169), 高等教育 の専門的被雇用者の中で女性が多数を占める唯一のカテゴリーである支援専門職 ${ }^{(15)}$ と教員集団や学生集団の間での複雑な相互作用はどのようなもので, それらは大学 全体の変化とどのようにかかわっているのか（同上書, p.177）など。これらは日 本の大学を対象とした場合にも重要な研究課題となるだろう。特に, 今日のジェン ダー社会学が, 人種・民族, 階層, 障害等の諸変数とジェンダーとの交差性 (intersectionality）をめぐる議論として展開していることに鑑みれば，上記 Rhoades に よる指摘は, 狭義の女性研究者研究に留まらず, 多様化する大学教授職の実態を多 角的に探究する上での有用な分析枠組みのひとつとなるはずだ。

次に, ここまでの議論は, 第 2 の課題としてあげた質的アプローチの視点に密接 
にかかわっている。たとえば上掲 Hart（2006, p.43）はその考察の中で，社会学領 域で女性研究者の方がより多く質的調査法を用いた研究発表を行う傾向があること を併せて指摘した。この指摘の背景には, 周知のとおり, 第二次世界大戦後の行動 科学全盛期に「ロスト・アート」（佐藤 2006, p.26）としていったんは低迷した 質的研究が，その後フェミニズムや公民権運動等の社会運動の高まりと時期を同じ くして再興した歴史的経緯がある（Denzin and Lincoln 訳書, 2006, pp. 7-28)。 この歴史的展開は, 単に調査「技法」の議論に留まらず, 科学社会学的な問題提起 一一従来の知の生産過程において「正当な知」を選別するマジョリテイ視点での基 準の自明性そのものへの問い直し——含むものであった。知のあり方をめぐるラ デイカルな問題提起は, 教育社会学にも大きな影響を与えた。特に, ポストモダン と融合した近年のフェミニズム教育研究の特徴のひとつは,「知識」生成秩序に埋 め込まれた権力性の問い直し，すなわち，既存研究における「知」と「知ではない もの」を区分する旧来の男性視点での常識そのものを懐疑する視点にあるとされる (多賀・天童 2013, pp.122-123)。実際，初等・中等教育などを対象とした最近の 研究においては，こうしたポストモダニズムを織りこんだフェミニズムの視点のも と, グローバルなネオリベラリズムのなかで変容する教育現場でのジェンダー化 . 人種化・階層化された体験が多角的に解明されている（優れた研究例として Ringrose 2012など)。こうした教育社会学領域での優れた研究例は, テーマや対象 が異なるが故にこれまで大学教授職研究とは分断され, 直接参照されることが少な かった。しかし，今日の大学教員を取り巻くグローバルなネオリベラリズム化の実 態と影響を精緻に分析するためには, これらの関連周辺領域での研究成果は, 有用 な資源となるだろう。

本稿のテーマにおいて興味深いのは, このように20世紀後半以降マイノリティ調 査研究法の領域で提起されたメタレベルでの認識論上の問いを, 大学教授職研究も また別の形で共有してきた点だろう。たとえば，研究主体と観察対象の区別を疑い そこに埋め込まれた権力性を問い直すフェミニスト・リサーチの考え方, あるいは, 研究者の経験・主観も戦略的に活用するエスノグラフィーのアウトプット法は, 自 らを研究の対象とするタブーに挑戦したことで, 結果として伝統的な教育研究の常 識を塗りかえてきた高等教育研究者の挑戦（有本 2005a）と, 決して無関係では ないはずだ。

なお，紙幅の関係で詳細は割愛するが，質的研究と量的研究を分断するのではな く質量混合研究の可能性を積極的に探究することも, 今後取り組まれるべき必須の 
課題である。特に, 近年のキャリアの多様化を詳述するためには, たとえば研究室 でのエスノグラフィーと既存の大規模調査との併用など, 多様な方法の組み合わせ による発展が期待される ${ }^{(16)}$ 。

最後に，本節と関連する社会問題についても，若干の補足をしておきたい。紙幅 の関係で個別のテーマについては詳述できないが, 教職員同士や教員一学生のかか わりにおいて生じるハラスメント問題（湯川 2014など）, 国際競争とローカルな 組織文化の重なりの中で生起する様々な研究不正（Yukawa et at. 2014）などは, ジャーナリスティックな媒体で繰り返し報じられる一方, その社会学的な調査研究 は少ない。それは, 初等・中等教育のフィールドでは一定程度実践可能な教育現場 の観察研究（とりわけその負の側面も含めた考察）が, 高等教育研究ではいまだ困 難な現状を示している。だが，質的調査研究全体へ視線を転じてみると，「マック レイキング」（既存体制の問題点を浮かび上がらせるやり方）の点で部分的に ジャーナリズムの手法と重なりうる学術的試みも多く存在してきた（Bogdan and Taylor 1990, p.184など)。こうした社会調査の歴史に照らせば, シカゴ学派以来 数多くの「ジャーナリスティックなセンスをもった社会学」（佐藤 2006, p.64） を生み出してきた質的アプローチの利点を, これからの大学教授職研究に取り入れ ることもできるはずだ。そうすることによって，大学教員がアクターとなる社会問 題に向けられた社会的関心に対して, 社会学研究の立場から応答することができる のではないか。

\section{2. マクロレベル：男女共同参画政策と大学教授職}

本節では，日本でも近年政策として進められている大学での男女共同参画の現状 を確認した上で大学教授職研究に求められる研究課題を指摘したい。

まず現状として多くの国で女性研究者の少なさが課題とされており，日本もその 例外ではない。学部, 修士課程, 博士課程と課程を進むごとに, さらに大学教授職 では女性が減ることが知られている。職階が上がるごとに, さらに学部長や学長な どの管理的地位では女性が大幅に減る。分野による違いも大きく, STEM（Science, Technology, Engineering and Mathematics）などいわゆる理系では女性が少 ない。国公私立などの設置者別, 大学と短大の種別, それらに伴う大学の威信に よっても所属する男女の割合が異なり, 例えば威信の高い機関では女性が少ないこ とが指摘されてきた。これらのジェンダー差の原因解明については多くの蓄積があ る。配偶者・パートナーの有無・職種や家族との同別居についてのジェンダー差を 
明らかにしたり，妊娠・出産，介護などのライフイベントがキャリアに与える影響 のジェンダー差を明らかにする研究，あるいは研究と教育への時間配分・意識や ネットワーク形成のあり方の違いを示唆する研究などがある（天野 1978, 坂東ほ か 1981, 塩田 1984, 登谷·坂東 1985, 加野 1988, 2007, 原 1999, 坂田 - 山 浦 2000, 河野ほか 2008, Schiebinger et al. 2008, 木本 2008, 仲 ·久保 2014ほか)。

これらのジェンダー差に対して女性研究者や組合など当事者による運動が長年行 われてきた。しかし近年特に注目すべきこととして, 国が大学の男女共同参画, 特 に女性研究者増加のための政策を導入している点がある。具体的には2006年度から 国は女性研究者支援モデル育成事業（「ダイバーシティ研究環境実現イニシアティ ブ」など数度の名称変遷があるが以下本稿ではこの名称で表記）を開始し，国の科 学技術基本計画の中でも女性研究者の採用の数值目標が設定されているなど，女性 研究者の増加が促されている (坂無 2018ほか)。政策をうけて各大学では女性研 究者支援室, 男女共同参画推進室, ダイバーシティ推進室などの担当部署が作られ, 様々な取り組みが行われている。具体的には，学内保育所の整備などワーク・ライ フ・バランス支援のほか, いくつかの大学では女性限定の教員公募が行われるなど 大きな変化がある。

このように実態としては大学と大学教授職のあり方が大きく変わっている一方, 大学教授職研究からの知見の提供と批判的検討が圧倒的に不足している。政策の導 入については，一方ではアメリカや欧州など海外の政策がモデルとされ（小川 2012ほか)，もう一方では男女共同参画学協会連絡会など研究者当事者の団体によ る働きかけによって政策が導入されている（横山ほか 2016, 巽 2018）など経緯 についての知見はある。しかし，現在大学で実際どのようなことが起きており，ど のように大学が変わっているかについて, 大学教授職研究からも知見を提供するこ とが課題といえるだろう。

女性研究者支援モデル育成事業は国の公募に対して大学・機関が申請し，採択さ れるものである。そのため, 事業実施の時間経過や実施方法によって当然差異があ るだろうが少なくとも当初は，事業の申請や実施に直接関与する教職員，支援対象 となる研究者, ジェンダー平等や男女共同参画に強い関心を持つ研究者以外の構成 員が深く関わることは，筆者の一人がスタッフとして関わった経験などからは多い とはいえない。

ここで問題にしたいのは上記の大学の構成員における関心と議論の不足だけでは 
なく, 大学教授職研究からの批判的な検討が不足している点である。その理由は, まずはこの政策が比較的近年になって本格的に始まったということにあろう。また, もともと女性研究者が少ないSTEM の女性増加を中心的な目的としたものである ため, 採択大学は当初は大規模な理工系学部を持つ国立大学が中心であった。その こともあり，いわゆる文系が多い大学教授職研究者のアンテナにかかりにくかった ということもあろう。さらに重要なこととして大学教授職研究の担い手に男性が多 いこともあるかもしれない。

学術界では専門職集団としての積極的な動きもある（日本学術会議, 理工学系学 協会の「男女共同参画学協会連絡会」,「人文社会科学系学協会男女共同参画推進連 絡会 GEAHSS」ほか)。大学教授職研究の役割のひとつとして, 信頼に足る知見の 提供からそれらの動きに貢献することがあろう。また各大学で支援を行うスタッフ には自然科学系の研究者や事務職のキャリアを持つ人のほかにも, 社会学, 教育学, ジェンダー研究などの研究者が含まれている。巽（2018）は大学における男女共同 参画コーディネーターの幅広い業務と専門性について考察している。各大学の現場 で蓄積されている問題関心や経験と, これまでの大学教授職研究の知見を相互交流 することができれば，大学での男女共同参画をより一層進めること，また大学教授 職研究自体の射程を広げ，深めることができる可能性がある。

ここではその一つの例として, 現在いくつかの大学で行われている女性限定公募 など採用や昇進に関わるテーマが, 大学教授職研究の知見からどのように捉えられ, どのような研究の方向性があるか考えてみたい。まず, 大学教授職研究にとって重 要なテーマのひとつは大学教授職の属性・業績・地位配分の 3 者の関係についての 分析である。Merton（訳書，1961）の普遍主義によれば少なくとも理念的には, 大学教授職の褒賞や地位配分は個人の属性ではなくその個人がなしとげた業績によ る。そのため, 大学教授職の地位配分が本当に普遍主義にもとづいているのか, そ れとも人種や性別などの属性によるのか, あるいは半ば属性化した業績（梶田 1981ほか) によるものかなどの分析が重要なテーマとなってきた。

大学教授職研究にとって重要なテーマは, 属性と業績の関係, 業績と地位の関係, 属性と地位の関係，あるいは 3 者を総合的に捉えた分析であろう。例えば，性別と いう属性と業績の関係について限ってみると, 坂無（2015）もまとめているように 研究業績を従属変数とし, 性別を独立変数, それ以外の複数の変数を統制変数とし た回帰分析などの研究蓄積がある（Kolpin et al. 1996ほか）。学閥を属性と捉えれ ば学閥研究もここに分類できよう。業績と地位配分にかんしては, 例えばLong ら 
（1993）は, アメリカの生化学の研究者の業績の量と質を独立変数, 昇進を従属変 数とするイベントヒストリー分析を行っている。

これらは大学教授職という小さな市場の分析にとどまるのではない。大学教授の 分析は社会全体の属性・業績・地位配分の関係を分析する戦略的地位を占める。と いうのは大学教授職の属性・業績・地位は他の職業に比べ把握しやすいという利点 があるためである。大学教授職は個人の業績が把握しやすい。特に研究業績（研究 生産性）は組織名ではなく個人の名前で出される。そのためもあり研究業績を変数 とした知見の蓄積（山崎 1995ほか）は多い（研究生産性についての詳細なレ ビューは原田（2012）など）。

このような属性・業績・地位配分の関係の分析には属性，業績，地位の概念を操 作化することが必要になる。もちろん業績のうち研究業績の指標化だけでも共著, 著者順，期間，論文・著書の区別を考慮する必要など多くの課題が指摘されている。 量ではなく質については Impact Factor や引用度などを使うこともある。しかし， 例えば牧野ら（1997）は，論文生産性・引用度と科学者集団内部での評価や基準が 異なることを指摘し, 山崎（2004）は Impact Factor は雑誌選定のための指標で研 究生産性の指標としては必ずしもふさわしくないことを指摘している。研究以外の 教育, 管理業務, 社会貢献などの活動を捉えることはさらに難しいだろう。地位に ついても職階とともに役職や所属大学の威信, また学会や地域社会での地位など考 慮すべき点は多い。さらに属性については，3.1でも述べたように分析の独立変数 として単に男女という性別を扱うにとどまるのではなく, 性別という変数自体を フェミニズムやジェンダーの視点から捉え直すことも必要かもしれない。

また，属性・業績・地位配分の関係の分析には研究者の長期的なキャリアを捉え るために, 継続的なデータや回顧的な調査が必要であろう。ただし, その際忘れて はならないのは，研究者ではないキャリアを選んだんたちの声をいかに拾うかとい う課題である。たとえば, Sonnert and Holton（1995a, 1995b）のアメリカの調査 では, 若い時に研究能力が高いと認められたが研究と異なるキャリアに進んだ人へ も調査が行われている。日本でも研究者キャリアではない道を選んだ人たちを含め た研究が求められよう。

このように考えると, 先述の女性限定公募など採用や昇進に関わるテーマは, 属 性・業績・地位配分など大学教授職研究がまさに王道として取り組んできたし，ま た取り組むべきテーマであることがわかる。大学が直面している現在の課題の解決 のためにも, 大学教授職研究の精緻化と理論的な発展のためにも, ジェンダー視点 
での大学教授職研究が重要な研究テーマの一つとなろう。

\section{4. まとめ}

大学教授職研究は，その黎明期より，学閥と結びついたインブリーディングの日 本的特質の解明, 日本の大学教員の教育負担の多さなど, 常に国際比較の視点を内 在した斬新なテーマ課題を設定し，意欲的に調査研究を積み重ねてきた。「専門職 を生み出す専門職」である大学教授職の研究は, 高等教育研究内部の単なる一分野 にとどまらず，知の生産と伝達のあり方を論じる教育社会学全体にとっても重要な 意味をもつテーマ領域である（1 節)。その点でも, 大学教員の生活世界の解明を タブー視せず観察対象として位置づけた既存研究の貢献は大きい。本稿では，まず， こうした既存研究による成果と到達点を振り返る作業を通じて, 教育社会学におけ る大学教授職研究の重要性を改めて再確認した（ 2 節 1 項）。

一方，そのはじまりにおいてどのように先駆的で優れた研究関心であっても，一 定の枠組みを前提とした調査・解析が継続的に実施され安定化する過程では，ある 種の定型化や思考の盲点・死角が生じやすい。そうした状況は，時に，調査そのも のの目的化や, 急速に変化する社会状況を背景とした現場の現実感覚と研究者側の 意識との乘離なども生み出す。本稿は, そうした現状を当該研究分野がその成熟ゆ えに直面する今日的な挑戦課題として位置づけた。そして，それらの課題に向き合 うためには，いまいちど原点に立ち返り，「専門職の社会学」研究としての理論 的・学問的意義づけを改めて明確にする志向性をもち, さらにより洗練された方法 論的展開を促すことが不可欠であることを論じた（2 節 2 項， 3 項）。

上記の問題意識のもと, 続く 3 節では, 特に(1)ほとんど研究蓄積がなされていな いミクロレベルでの相互作用の研究，また，(2)一定の議論蓄積はありながらも政策 的関心が先行しがちな男女共同参画をめぐるマクロレベルでの政策研究における課 題や論点という 2 つのサブテーマを事例的に掘り下げる形でのレビューを行い, 今 後の新しい研究展開の方向性を模索した。(1)のミクロレベルについては，まず，大 学教授職研究における相互作用研究の圧倒的少なさが, 理論的には「批判的な社会 学」の視点の不足から, 方法論的には質的アプローチの不足から生じていることを 指摘した。その上で, 既存研究が大学教員集団を描く際に前提視してきた単一的な マジョリティ集団としてのイメージを見直し, 複数の社会学的変数から成る多様性 ある集団として捉えなおすことを提案した。また，そうした発想転換の先に，大学 教員のキャリア形成, 日常活動, 組織文化などをめぐるより現実に即した分析の深 
化が期待できることを論じた（ 3 節 1 項）。(2)のマクロレベルについては, 政策と して男女共同参画が進められ大学が変わりつつある一方，大学教授職研究からの批 判的検討と知見の提供が圧倒的に不足していることを指摘した。特に, 属性, 業績, 地位配分というそれ単体では関心の集まりやすいトピックの相互の関倸性が十分に 分析されていない現状に注目し，その足がかりとなる分析の可能性を論じた（3節 2 項)。

なお，本稿は専門を異にする 3 名での協働執筆であり，個別論点をめぐり必ずし も全面的に見解を共にしているわけではない。その中で，本稿ではジェンダーの視 点をとりわけ重視した。それは，当該領域におけるジェンダー視点の圧倒的欠如が, 専門を異にする 3 名の筆者らをつなぐ共通理解であったからにほかならない。ただ し, 本稿はジェンダー研究をはじめ「批判的な社会学」からのラディカルで非伝統 的な研究のみを無条件に推奨しているわけではない。たとえば,「批判的な社会学」 の視点はときに研究のドグマ化を導きやすいなど問題点も孕む（Burawoy 2005, p.17）という指摘には，十分留意する必要がある。実際，高等教育研究コミュニ ティの外部から提出される批判的視点での大学研究の一部には, サンプリングや分 析に扔いて問題点が多く残るものや予定調和になりがちな考察結果などもある。

大学教授職研究がいま取り組むべきことは，単にそれらのオルタナティヴな試み を無視し，既存研究コミュニティの枠組み内部での循環に閉じこもることではない。 むしろ, 専門研究コミュニティ外部の問題意識とつながる形で, これまで蓄積して きた専門知見を開きながら活用し，より広い範囲での建設的批判や対話を主導する ことで，当該領域の研究の裾野をさらに広げることができるのではないだろうか。

もちろん, 本稿は, あくまで試論として限定的な論点整理を行ったに留まり, 本 稿で扱いきれなかったテーマや課題も多く残る。たとえば, 羽田（2011）により， FD の再検討を通じて, 伝統的な大学教授職研究の範囲や枠組みを再編する必要性 も提示されており, 高等教育研究者の中からも批判的検証の声はあがっている。関 連する周辺領域研究とつながり, 継続的な対話の基盤が作られることが望まれる。

〈注〉

（1）本稿は 3 名で協議の上分担執筆している。主な担当箇所は， 1 節・2 節（村 澤・坂無）， 3 節 1 項（湯川）， 3 節 2 項（坂無）４４節（湯川・村澤）である。

(2) 国外において大学教授職調查に依拠した研究例としては, Cummings \& Finkelstein（2012）, Teichler, et al（2013）などがある。 
(3) 黄（2018）による外国人教員研究はある。

(4) 代表的なものとして, 広島大学高等教育研究開発センター編（2005）がある。

（5）たとえばアメリカでは, 非常勤講師やノンテニュアトラック教員への依存は, 授業以外での学生との交流が無いため学生への指導が不足する点, 研究をしない （できない）点, 管理運営に参加しない点等から, 質の低下を招くと指摘されて いる (American Council of Education 2004)。

（6）ただし，実務的・現代的課題と研究者の関心との乘離については，クラーク （Clark 訳書, 2015, p.415）とガムポート（Gumport＼cjkstart訳書, 2015, p.429-430) は対照的である。

（7）たとえば山野井（2007）は，流動性を，研究生産性の手段として位置づけてい るが, 研究生産性の高さ故の流動可能性の高さの側面には着目していない。

（8）高等教育研究の計量分析の課題については村澤 ·立石（2017）を参照。研究業 績の分布に配慮した研究として, 坂無（2015），中尾・村澤（2018），藤村 （2017）がある。

（9）自戒を込めて言えば，学会・国際会議での発表や報告書・書籍を通じた発信が 多く，査読誌への投稿・掲載が限定的であり，ピア・レビューを経た質の担保が 必要である。

(10) この点については，ガムポート（Gumport 訳書，2015，p.436）の言及を見よ。

(11) 同書は広く大学院生の経験に焦点を当てるものであるが, その社会化過程を社 会化理論の枠組みのなかで解明しようとする知見は, 大学教授職研究にも示唆を 与えるものである。

(12) なお，システムレベルを扱った研究としては濱中（2009）の大学院教育研究が ある。

(13) 主要な文献は3.2. であげる

(14) シスジェンダーとは, 出生時の性別と本人が自認するジェンダー・アイデン ティティが一致しており，それに従って生きる人々のことを指す。

(15) ここでいう支援専門職とは，たとえばリサーチ・アドミニストレーターなどの 研究支援をはじめ, 学生のキャリア支援, 障害のある学生の学習支援に関わる ソーシャルワークや臨床専門職など, 大学内で活動する教授職以外の様々な専門 職を総称する言葉として用いている。なお, Rhoades（訳書, 2015, p.170）は, この支援専門職に対して, 教員職カテゴリーと経営カテゴリをつなぐ含意をもた せるため「管理専門職」という独自のタームを割り当てて分析している。 
(16) たとえば, Sonnert and Holton（1995a, 1995b）はアメリカの NSF や NRCの ポスト・ドクトラル・フェローに選ばれたという意味でキャリア初期に研究者と して高い能力が認められた男女に対して量的調査と質的調査を組み合わせた大規 模な研究を行っている。必ずしも混合研究法 (mixed method research) として 明確な位置づけはされていないものの, 質量両面からの多角的な探究により, 家 庭要因のキャリアへの影響の多様性や, 女性研究者固有の生存戦略などをジェン ダーの視点から描き出している。

\section{〈参考文献〉}

天野正子, 1978, 「女性研究者の地位と役割構造」『金城学院大学論集 社会科学編』 21, pp. $1-22$.

American Council of Education, 2004, An overview of Higher Education in the United States: Diversity, Access, and the Role of the Marketplace. (https:// www.acenet.edu/news-room/Documents/Overview-of-Higher-Education-inthe-United-States-Diversity-Access-and-the-Role-of-the-Marketplace-2004. pdf, 2019年 2 月 12 日現在)

有本章, $2005 \mathrm{a}$,「高等教育研究40年の回顧」『広島大学高等教育開発センター大学 論集』, 第35集, pp.59-86.

有本章, 2005b, 『大学教授職と FD アメリカと日本』東信堂。 有本章, 2016, 『大学教育再生とは何か一大学教授職の日米比較』玉川大学出版 部。

有本章・江原武一, 1996, 『大学教授職の国際比較』玉川大学出版部。 有本章編, 2008, 『変貌する日本の大学教授職』玉川大学出版部。 有本章編, 2011, 『変貌する世界の大学教授職』玉川大学出版部。 阿曽沼明裕 (編), 2010, 『大学と学問 知の共同体の変貌』玉川大学出版部. 坂東昌子 ·野口美智子 ·新山陽子編, 1981, 『女性と学問と生活一一婦人研究者の ライフサイクル』勁草書房。

Bogdan, Robert and Steven Taylor, 1990, “Looking at the Bright Side:A Positive Apporach to Qualitative Plolicy and Evaluation Resarch, Qualitive Sociology, 13 ( 2 ), pp.183-192.

Bourdieu, Pierre et Jean-Claude Passeron, 1970, La reproduction: éléments pour une théorie du système d'enseignement, Paris: Les Éditions de Minuit, (=1991, 
宮島喬訳『再生産——教育 · 社会 · 文化』藤原書店).

Boyer, Ernest L., 1990, Scholarship Reconsidered: Priorities of the Professoriate. The Carnegie Foundation for the Advancement of Teaching. (=1996, 有本章 訳『大学教授職の使命一スカラーシップ再考一』玉川大学出版部)

Burawoy, Micheal, 2005, “2004 ASA Presidential Address: For Public Sociology”, American Sociological Review, 70 ( 1 ), pp. 4-28.

近田政博, 2008, 「社会人大学院生を対象とする研究方法論の授業実践」『名古屋高 等教育研究』 8, pp.73-94.

Clark, Burton R., 2007, “A Note on Pursuing Things that Work”, P.J. Gumport, Sociology of Higher Education Contributions and Their Contexts, Johns Hopkins University Press, pp.319-324.（=2015，伊藤彰浩・橋本鉱市・阿曽沼明裕編訳 『高等教育の社会学』玉川大学出版部).

Cummings, William K., and Finkelstein, Martin J., 2012, Scholars in the Changing American Academy: New Contexts, New Rules and New Roles, Springer.

大学非常勤講師問題会議編, 2000, 『大学危機と非常勤講師運動』こうち書房。

Denzin, Norman.K. and Yvonna S. Lincoln, 2000, "Introduction: The Discipline and Practice of Qualitative Resaerch”, IN Denzin and Lincoln eds., Handbook of Qualitative Research, $2^{\text {nd }}$ Edition, Sage Publication（=2006, 平山満義監訳 · 藤 原顕編訳『質的研究ハンドブック 2 巻』, 北大路書店, pp. 1-28).

藤村正司, 2017, 「なぜ研究生産性が失速したのか? 一大学教員の現在一」『大学論 集』第50集, pp. 1-16.

Gardner, Suzan K. and Lilar Mendoza, 3 ds, 2010, On Becoming Scholar: Socialization and Development in Doctoral Education, Virginia: Stylus Publicatoin. Gumport, Pagricia J. (Eds.), 2007, Sociology of Higher Education Contributions and Their Contexts, Johns Hopkins University Press, pp.325-362. (=2015, 伊 藤彰浩 ·橋本鉱市 · 阿曽沼明裕編訳『高等教育の社会学』玉川大学出版部).

Gumport, Patricia J., 2007, "Reflections on a Hybrid Field: Growth and Prospects for the Sociology of Higher Education”, Gumport, Pagricia J. (Eds.), Sociology of Higher Education Contributions and Their Contexts, Johns Hopkins University Press, pp.325-362.（=2015, 伊藤彰浩・橋本鉱市・阿曽沼明裕編訳『高等教 育の社会学』玉川大学出版部).

濱中淳子, 2009, 『大学院改革の社会学一工学系の教育機能を検証する』東洋館出 
版。

原田健太郎, 2012, 「大学での知識の生産・整理・伝達に関する研究一一日本にお ける研究動向のレビュー」『大学論集』第43号, pp. 239-254.

原ひろ子編, 1999, 『女性研究者のキャリア形成——研究環境調査のジェンダー分 析から』勁草書房。

Hart, Jeni, 2006, "Women and Feminism in Higher Education Scholarship: An Analysis of Three Core Jounarls", Journal of Higher Education, 77 ( 1 ), 40-61. 羽田貴史, 2011, 「大学教員の能力開発をめぐる課題」『名古屋高等教育研究』第11 号, pp.293-312.

広島大学高等教育研究開発センター編, 2005, 『わが国の大学教員に関する人事政 策 II：任期制の導入 ·実施・再任の分析を中心に』（COE 研究シリーズ14）広島 大学高等教育研究開発センター。

梶田孝道, 1981, 「業績主義社会のなかの属性主義」『社会学評論』第32巻 3 号, pp.70-87.

加野芳正, 1988, 『アカデミック・ウーマン——女性学者の社会学』東信堂。 加野芳正, 2007, 「第 7 章 女性教員の大学教授市場」山野井敦徳編『高等教育シ リーズ142 日本の大学教授市場』玉川大学出版部, pp.168-89. 河野銀子・佐藤香・藤森宏明, 2008, 「第 3 章 女性大学教員のキャリア・ライフス タイルと地域との関わり」, 米澤彰純・佐藤香編『大学教員のキャリア・ライフ スタイルと都市・地域——大学教員の生活実態に関する調査」から（高等教育 研究叢書96)』広島大学高等教育研究開発センター, pp.41-59.

Kernan, Alvin (eds.), 1997, What's Happened to the Humanities?, NewJersey:

Princeton University Press. (=2001，木村武史訳『人文科学に何が起きたか一 アメリカの経験』玉川大学出版部. )

黄福涛，2018，「理工系における外国人教員の特徵と意識」『応用物理』第 87 巻第 12 号, pp.940-942.

木本尚美, 2008,「ジェンダー・バイアス一一性教員の何が変化したのか」有本 章編『変貌する日本の大学教授職』玉川大学出版部, pp.123-42.

喜多村和之, 1996, 「非常勤講師という存在一現状と将来」『IDE 現代の高等教 育』381, pp. 5-14.

北野秋男, 2015, 『ポストドクター一若手研究者養成の現状と課題』東信堂。

Kolpin, Van W. \& Larry D.Jr. Singell, 1996, “The Gender Composition and Schol- 
arly Performance of Economic Departments: A Test for Employment Discrimination”, Industrial and Labor Relation Review, Vol.49, No. 3, pp.408-23.

神代和欣, 2016, 「労働政策の展望 我が国の老後所得保障政策の問題点一大学教 授の退職給付の国際比較を中心として一」『日本労働研究雑誌』No.672, pp.64-75. 川成洋, 1995, 『だから教授は辞められない一大学教授解体新書』ジャパンタイム ズ。

Long, J. Scott, Paul D. Allison and Robert McGinnis, 1993, "Rank Advancement in Academic Careers: Sex Differences and The Effects of Productivity", American Sociological Review, Vol.58, No. 5, pp.703-22.

牧野淳一郎・藤垣裕子.今井良行, 1997, 「科学研究における研究グループの生産 性と質的評価一引用度分析とコミュニティ内評価の相互関係」『年報 科学 技術 社会』第 6 集, pp.85-99.

Merton, Robert K., [1949] 1957, Social Theory and Social Structure: Toward the Codification of Theory and Research, New York: Free Press, (=1961, 森東吾 · 森好夫・金沢実・中島竜太郎訳『社会理論と社会構造』みすず書房).

Merton, Robert K., 1979, The Sociology of Science, Theoretical and Empirical Investigations, Chicago: University of Chicago Press.

Mills, Charles Wright, 1959, The Sociological Imagination, New York: Oxford University Press, (=1984, 鈴木広訳『社会学的想像力』紀伊國屋書店).

水月昭道, 2007, 『高学歴ワーキングプア〜「フリーター生産工場」としての大学 院 $\sim$ 光文社。

村澤昌崇・立石慎治, 2017, 「計量分析の新展開一過去10年間の経験を振り返って 一」『高等教育研究』第20集, pp.135-156.

仲真紀子 · 久保（河合）南海子, 2014, 『女性研究者とワークライフバランスキャ リアを積むこと，家族を持つこと』新曜社。

中尾走・村澤昌崇, 2018, 「大学教員の生産性分析：再考一新たな計量分析の試 み：欠損值補完・サンプリングバイアス・“ゼロ”の意味の解釈一」広島大学高 等教育研究開発センター編『ディスカッションペーパーシリーズ』No. 9 , pp. $1-21$.

(http://rihe.hiroshima-u.ac.jp/wp/wp-content/uploads/2018/01/ 111b0d7e0ed42c98940c7a530de6bdb6. pdf, 平成31年 2 月12日現在）

日本障害者高等教育支援センター問題研究会, 2001, 『大学における障害学生支援 
のあり方』星の環会。

小川眞里子, 2012,「EUにおける女性研究者政策の10年」『人文論叢 三重大学人 文学部文化学科研究紀要』第29集, pp.147-62.

Ringrose, Jessica, 2012, Postfeminist Education?: Girls and the Sexual Politics of Schooling, Routledge.

Rhoardes, Gary, 2007, “The Study of the Academic Profession”, P.J. Gumport, Sociology of Higher Education Contributions and Their Contexts, Johns Hopkins University Press, pp.113-146.（=2015，伊藤彰浩・橋本鉱市・阿曾沼明裕編訳 『高等教育の社会学』玉川大学出版部).

坂無淳, 2015,「大学教員の研究業績に対する性別の影響」『社会学評論』第65巻 4 号, pp.592-610.

坂無淳, 2018, 「日本の高等教育と科学技術におけるジェンダー政策——男女共同 参画基本計画と科学技術基本計画を中心に」『福岡県立大学人間社会学部紀要』 第26巻 2 号, pp.19-35.

坂田桐子・山浦一保, 2000 ,「大学研究者のキャリア発達に及ほす対人関係の効果 —ジェンダーと専門領域による差異の検討」『産業・組織心理学研究』第 13 巻 1 号, pp.19-29.

佐藤郁哉, 2006, 『フィールドワーク増訂版』, 新曜社。

Schiebinger, Londa, Andrea Davies Henderson and Shannon K. Gilmartin, 2008, Dual Career Academic Couples: What Universities to Know, The Michelle R. Clayman Institute for Gender Research, Stanford University, (Retrieved February 1, 2019, https://stanford.app.box.com/s/y5bicy7o3cxwtmgy22iu).

新堀通也, 1965, 『日本の大学教授市場』東洋館出版社。

新堀通也編，1969，『学閥—この日本的なるもの』福村出版。

新堀通也, 1984, 『大学教授職の総合的研究』多賀出版。

塩田庄兵衛編, 1984, 『婦人研究者のライフサイクル調査研究 $\mathrm{V}$ 一 “アンケートに よる実態調査”の分析』文部省科学研究費総合研究 A (広領域) 研究成果報告書, 立命館大学。

Sonnert, Gerhard and Gerald Holton, 1995a, Gender Differences in Science Careers: The Project Access Study, Rutgers University Press.

Sonnert, Gerhard and Gerald Holton, 1995b, Who Succeeds in Science?: The Gender Dimension, Rutgers University Press. 
竹内洋, 2001, 『大衆モダニズムの夢の跡一彷彺する「教養」と大学』新曜社。 多賀太・天童睦子，2013，「教育社会学におけるジェンダー研究の展開—フェミ ニズム・教育・ポストモダン—」『教育社会学研究第93集 (2013)』, pp.119-50. 巽真理子, 2018, 「大学における男女共同参画推進コーディネーターは専門職にな り得るのか？——社会学を基盤にした専門職についての一考察」『現象と秩序』 第 8 号, pp.17-37.

Teichler, Ulrich, Arimoto, Akira, Cummings, William K. (Eds.), 2013, The Changing Academic Profession: Major Findings of a Comparative Survey, Springer. 登谷美穂子・坂東晶子, 1985, 「研究者の活動量とライフサイクル」『科学』4月号, pp.244- 9 .

筒井康隆, 1990, 『文学部唯野教授』岩波書店。

熟田小爾太, 1991, 『大学教授になる方法』青弓社。

渡邊聡，2014，「高等教育組織と退職給付制度：人材管理の視点からみたわが国へ の示唆と今後の課題」『大学論集』46, pp.73-89.

Weber, Max, 1919, Wissenschaft als Beruf, (=1980, 尾高邦雄訳『職業としての学 問』岩波書店).

山野井敦徳, 1990, 『大学教授の移動研究 学閥支配の選抜・配分のメカニズム』 東信堂.

山野井敦徳, 2007, 「第吕部 大学社会の流動性に関する研究」広島大学高等教育研 究開発センター編『大学政策・人材養成及び流動性に関する研究一研究システム 班報告書一』広島大学高等教育研究開発センター, pp.75-80.

山野井敦徳編, 2007, 『日本の大学教授市場』玉川大学出版部。

山崎博敏, 1995, 『大学の学問研究の社会学一日本の大学間および大学内の分業を 中心に』東洋館出版社。

山崎茂明，2004，『インパクトファクターを解き明かす』情報科学技術協会。 湯川やよい, 2014, 『アカデミック・ハラスメントの社会学一学生の問題経験と 「領域交差」実践』ハーベスト社。

YUKAWA, Yayoi, Chisato KITANAKA, Mieko YOKOYAMA, 2014., “Authorship Practices in Multi-Authored Papers in the Natural Sciences at Japanese Universities", International Journal of Japanese Sociology, (23), pp.80-91.

横山美和 ·大坪久子・小川眞里子・河野銀子・財部香枝, 2016,「日本における科 学技術分野の女性研究者支援政策——2006年以降の動向を中心に」『ジェンダー 
研究』第19号, pp. 175-191.

米澤彰純, 2010,「グローバル化と日本の私立大学」私学高等教育研究所編『高等 教育の公と私再考』, pp. 1-14. 
ABSTRACT

\title{
The Contributions and Potentialities of the Study of the Academic Profession in Japan
}

\author{
YUKAWA, Yayoi \\ (Aichi University) \\ 1-1, Machihata-cho, Toyohashi, Aichi, JAPAN 441-8511 \\ yayoiyukawa@gmail.com \\ SAKANASHI, Jun \\ (Fukuoka Prefectural University) \\ Ita 4395, Tagawa, Fukuoka, JAPAN 825-8585 \\ sknsj24@gmail.com \\ MURASAWA, Masataka \\ (Hiroshima University) \\ mrswm@hiroshima-u.ac.jp
}

1-2-2, Kagamiyama, Higashi-hiroshima City Hiroshima, JAPAN 739-8512

This paper reviews the results of the study of the academic profession and its contributions and potentialities. The first task of this paper is to reconfirm the importance of the study of the academic profession in the sociology of education (or educational sociology) by reviewing established research on this topic in Japan. The study of the academic profession in Japan has set cutting-edge research themes and accumulated a wealth of research findings from its beginning. The study of the academic profession is not only a minor subfield within higher education research but it is also one of the most important areas of focus within the sociology of education (or educational sociology), for the academic profession plays a critical role in knowledge production and knowledge transmission through educating other professions.

Second, this paper points out that the study of the academic profession faces the challenges of confronting the rapid changes affecting present-day universities and of contributing to an understanding of a situation where universities suffer so that this situation may be improved. There is a possibility of repetitive patterns and blind spots of research as the field of study is developed and formalized. However, the study of the academic profession requires theoretical arguments 
that re-situate it within the "sociology of professions", along with methodological sophistication in its surveys and analyses.

Third, this paper emphasizes gender perspectives in arguments over the future directions and potentialities of the study of the academic profession at both the micro and macro levels. At the micro level, interaction studies are extremely rare. The reason for this lack of a theoretical viewpoint from the perspective of critical sociology is a lack of theoretical qualitative approaches. Rethinking the university faculty as a diverse group in terms of gender and other factors can deepen analysis in line with the reality of present-day universities. At the macro level, gender equality policies affecting higher education that have been enacted by the Japanese government have changed universities dramatically. However, the study of the academic profession neither pays attention to the situation nor provides information in this area. For example, there is potential for an analysis of the relationships between the academic profession's attributes, performance, and the allocation of positions from a gender perspective.

Finally, this paper concludes by arguing that the study of the academic profession should move beyond its research community and adapt its rich tradition to society. Fostering dialogues in a wider realm can also contribute to broadening the scope of the study of the academic profession itself.

Keywords: study of academic profession, gender, sociology of professions 